\title{
Groundwater pesticides residue in the southwest of Iran-Shushtar plain
}

\author{
Ali Akbar Shahsavari • Kamal Khodaei • \\ Farhad Asadian · Farhad Ahmadi • \\ Seyed Mohammad Zamanzadeh
}

Received: 14 March 2010/Accepted: 26 April 2011/Published online: 18 May 2011

(c) The Author(s) 2011. This article is published with open access at Springerlink.com

\begin{abstract}
Study area with an area of about $415 \mathrm{~km}^{2}$ is located from $31^{\circ} 40^{\prime}$ to $32^{\circ} 05^{\prime}$ northern latitudes and $48^{\circ} 45^{\prime}$ to $49^{\circ} 00^{\prime}$ eastern longitudes $85 \mathrm{~km}$ to the north-east of Ahwaz city, in the north of Khuzestan province, and south west of Iran. The purpose of this study is: (1) the determination of the pesticides concentration in the groundwater of the Shushtar plain (Mian- $\mathrm{Ab}$ ) and (2) the assessment of geology, hydrogeology and anthropogenic activities impacts the groundwater quality. Thirty-seven groundwater samples were taken from product wells based on the standard methods. A simple and efficient automated method for extraction and preconcentration was used. In this method, a pyrrole-based polymer was synthesized and applied as an efficient sorbent for micro-solid-phase extraction. After extraction, analytes were desorbed in ethyl acetate and analyzed using gas chromatographyflame. The study area is surrounded by Aghajari Formation dominated by silt and clay sediments and the Bakhtiari Formation dominated by sand andgravel. Existence of these formations affects the aquifer sediments and the hydrogeological properties. In the study area, the sediments grade from gravel and sand in the north and east into silt and clay to the south and west, respectively. The topsoil in
\end{abstract}

\footnotetext{
A. A. Shahsavari $(\bowtie) \cdot$ K. Khodaei $\cdot$ F. Asadian

Department of Geology, ACECR, Research Institute of Applied

Science, Shahid Beheshti University, Tehran, Iran

e-mail: aliakbar.shahsavari@gmail.com

F. Ahmadi

Pharmaceutical Chemistry Department, Faculty of Pharmacy,

Kermanshah University of Medical Sciences, Kermanshah, Iran

S. M. Zamanzadeh

Faculty of Geography, University of Tehran, Tehran, Iran
}

the south of the study area contains more clay sediments. In this study, the concentration of two common herbicides, i.e., 2,4-D and clodinafop propargyl and two pesticides, i.e., permethrin and diazinon, in the groundwater of Mian$\mathrm{Ab}$ aquifer was assessed. Chemical analysis results showed that the 2,4-D residue in the groundwater has the highest concentration $(15 \mathrm{ppm})$. About $50 \%$ of the samples have concentration values more than the maximum contamination level based on EPA drinking standard. The pesticides concentrations decrease from the north to the south of the study area. Pesticides influx to the groundwater in the south of the area is prevented or diminished due to the specific geological situation and soil type. Distribution pattern of population centers, which increase to the north of the study area, and the role of groundwater as the main source of drinking water are two important issues that must be considered in management of pesticides use in the area.

Keywords Groundwater quality · Pesticide residue · Khuzestan province

\section{Introduction}

Khuzestan province in the south-west of Iran with appropriate surface-water resources, topographical situation, and fertile soil is an important area for agricultural activities. The lack of a proper management has caused surface and sub-surface water resources contamination due to the utilization of excessive chemical fertilizers and poisons (including pesticides, herbicides, and insecticides).

Pesticides are chemical and biological materials that are used for pest removing or controlling, and are categorized into three main groups of insecticides, fungicides, and herbicides (Waxman 1998). In this study, concentration of 
two herbicides: 2,4-D and clodinafop propargyl and two pesticides: permethrin and diazinon, was investigated in the Mian-Ab, Shushtar groundwater. In this paper, the general term of "pesticide" is adopted instead of repeating the above-mentioned name.

Relation between human health, environment, and pesticides usage was heard after 20 years of using pesticides (Carson 1962) and their usage was related to cancer danger as well (UNEP 1993). It has been estimated that 2.5 million tons of pesticides are being applied worldwide each year and the usage continues with an increasing trend (Pimentel 1995).

Some farmers who work with 2,4-D suffer from neurotic illness, moreover digestive disease and prostate cancer related to 2,4-D have been registered based on the previous studies (Sierra Club of Canada 2005). 2,4-D causes slight decreases in testosterone release and significant increases in estrogen release from testicular cells (Liu et al. 1996). Workers applying chlorinated phenoxy herbicides frequently show nervous system disorders.

Human activities and natural factors that affect groundwater quality were studied around the world by many researchers (Jiang et al. 2009; Lorite-Herrera et al. 2007; Jalali et al. 2008; Kim et al. 2003; Shomar et al. 2005).

Based on the Chemical Security Profile information of Iran in 1996, about 27,000 tons of pesticides, including 101 types of insecticides, herbicides, fungicides..., were used in this country. Comprehensive and accurate information about pesticides utilization does not exist in the study area and this subject is a major source of worry about using pesticides.

Determination of residual pesticides in groundwater can help us to decide about groundwater management in an area (including cities and villages where the groundwater is utilized as drinking water supply). Some limited studies in Iran about pesticides residue in agricultural (Ebadi et al. 2005) and meat products (Hashemy-Tonkabony et al. 1981) have been carried out regardless of geological parameters.

Some studies on the surface-water and agricultural wells around Tehran city have been done to determine 13 organophosphorous pesticides; in these samples diazinon, malathion, and etion have been extracted from water and the results show that their concentration was lower than EPA maximum contaminant level (Ahmadi et al. 2006).

2,4-D is one of the pesticides that is mostly used in the study area. Some other pesticides such as permethrin, clodinafop, diazinon, atrazine, glyphosate, eradicane, are also used there. In the present study, permethrin, clodinafop, 2,4-D, and diazinon concentrations were determined in the groundwater in the study area.

The purpose of this study is: (1) the determination of the pesticides concentration in the groundwater of the Shushtar plain (Mian-Ab) and (2) the assessment of geology, hydrogeology and anthropogenic activities impacts the groundwater quality.

Agricultural activities are similar all over the plain, but geological and hydrogeological properties and soil types are different in the south compared to the north of the study area, so it is expected that the pesticides concentration in the groundwater in the northern part of the study area will be greater than in the southern part.

\section{Materials and methods}

\section{Study area}

Study area is the Shushtar (Mian-Ab) plain with an area of about $453 \mathrm{~km}^{2}$ and is located between $31^{\circ} 40^{\prime}$ and $32^{\circ} 05^{\prime}$ northern latitudes and $48^{\circ} 45^{\prime}$ and $49^{\circ} 00^{\prime}$ eastern longitudes some $85 \mathrm{~km}$ to the north-east of Ahwaz city, north of Khuzestan province, and south west of Iran. The Karun river at the entrance of the study area, near the Shushtar city, is divided into two branches: (1) Gargar river (eastern boundary) and (2) Shotait river (western boundary). These rivers again come together near to the Ghir dam after recharging the agricultural terrains. Mian- $\mathrm{Ab}$ Plain is bounded between the above-mentioned rivers (Fig. 1).

\section{Geology and hydrogeology}

Major formations around the study area are Aghajari and Bakhtiari Formations. Fine sediments with low specific yield and low hydraulic conductivity eroded from the Aghajari Formation containing gypseous sediments have formed the Mian-ab aquifer in the southern part. So the groundwater in the southern part of the study area is salty and is not suitable for irrigation and drinking (Fig. 2).

Sediments are almost coarser in the hillside of Bakhtiari Formation in the north and northwest of the study area with a hydraulic conductivity about $50 \mathrm{~m} /$ day and the hydraulic conductivity at the center and the south part of the area is about 30 and $10 \mathrm{~m} /$ day, respectively. Alluvial sediments, that are the youngest sediments in the study area, are composed of gravel, sand, silt and clay.

Based on the existing well logs in the study area, sandy and gravelly sediments in the northern part are dominant and they grade into silty and clayey sediments southward.

Well logs M28 (Shalili Kuchak), M53 (Konar Pir) and M54 (Yasarat) are located in the same geographic latitude (Fig. 3). Geological assessment of well logs in the northern part of the study area illustrates a clayey layer which thickens eastward. The clayey layer thicknesses in the well logs M54, M53 and M28 (near the Gargar river) are about 3,5 , and $12 \mathrm{~m}$, respectively. These wells are located about 
Fig. 1 Study area and location of sampling points

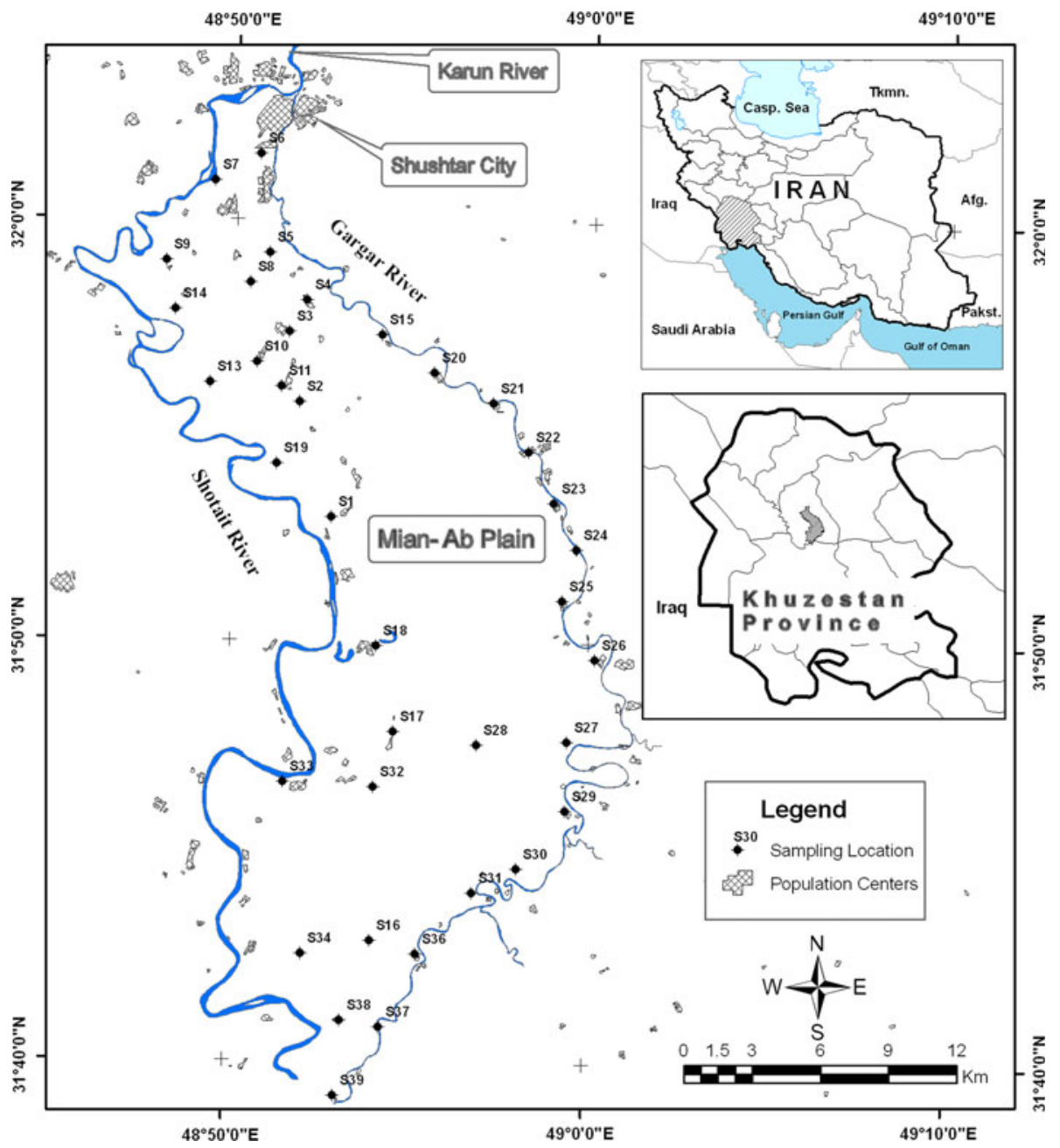

$5 \mathrm{~km}$ apart from each other. Sandy and gravelly sediments exist in all three well logs beneath this clayey layer. Geophysical investigations also confirm this (Khuzestan Water and Power Authority 1987). Therefore, thickness of the clayey layer increases from the north to the south and from the west to the east meanwhile the grain size gets finer as well. Coarser grains have been completely removed from sediments of the central part of the plain southwards except for the sediments bordering the Shotait river.

Therefore, the Mian-ab aquifer is an unconfined aquifer dominantly and in some parts in the north of the plain where the clayey layer extends, the aquifer becomes confined especially near the Gargar river (Fig. 4). The aquifer average thickness is about $75 \mathrm{~m}$ with clay bedrock related the Aghajari Formation.

The dominant soil texture is heavy in the Mian-ab plain and it also becomes heavier from the north to the south. In the north of the plain where the Karun river enters into the study area, soil texture is light with high infiltration potential. Since the soil type is heavy in the central part, the infiltration potential is low and it is also very heavy in the south and southeast so that the infiltration is very low (Mahab Ghods Consultant Engineering 1986).

Maximum depth of groundwater is about $18 \mathrm{~m}$ in the north and southeast and minimum depth of groundwater is about $2 \mathrm{~m}$ in the center of plain based on the water level data obtained from piezometers located in the study area. General groundwater flow direction is from the north to the south and the groundwater recharges the surface-water along the Shotait river. But flow direction of the groundwater along the Gargar river is toward the aquifer and the river recharges the aquifer based on the groundwater model results using MODFLOW 2000 code. So there are interactions between the Shotait and Gargar rivers and the groundwater (Fig. 5). The vulnerability in the northern part of the study area is greater than the southern part of the study area according to the parameters affecting the vulnerability, including hydraulic conductivity, surface recharge, soil type, impact of vadose zone and topography. Then, it is expected that the pesticide concentration to be high in the groundwater samples gathered from the northern part with higher vulnerability. 
Fig. 2 Geological map of the study area including Aghajari $(A J)$, Bakhtiari $(B K)$, and Mishan $(M N)$ Formations Lahbari member $(L B M)$ and Quaternary $(Q)$ Sediments and the Hydrogeological profile location

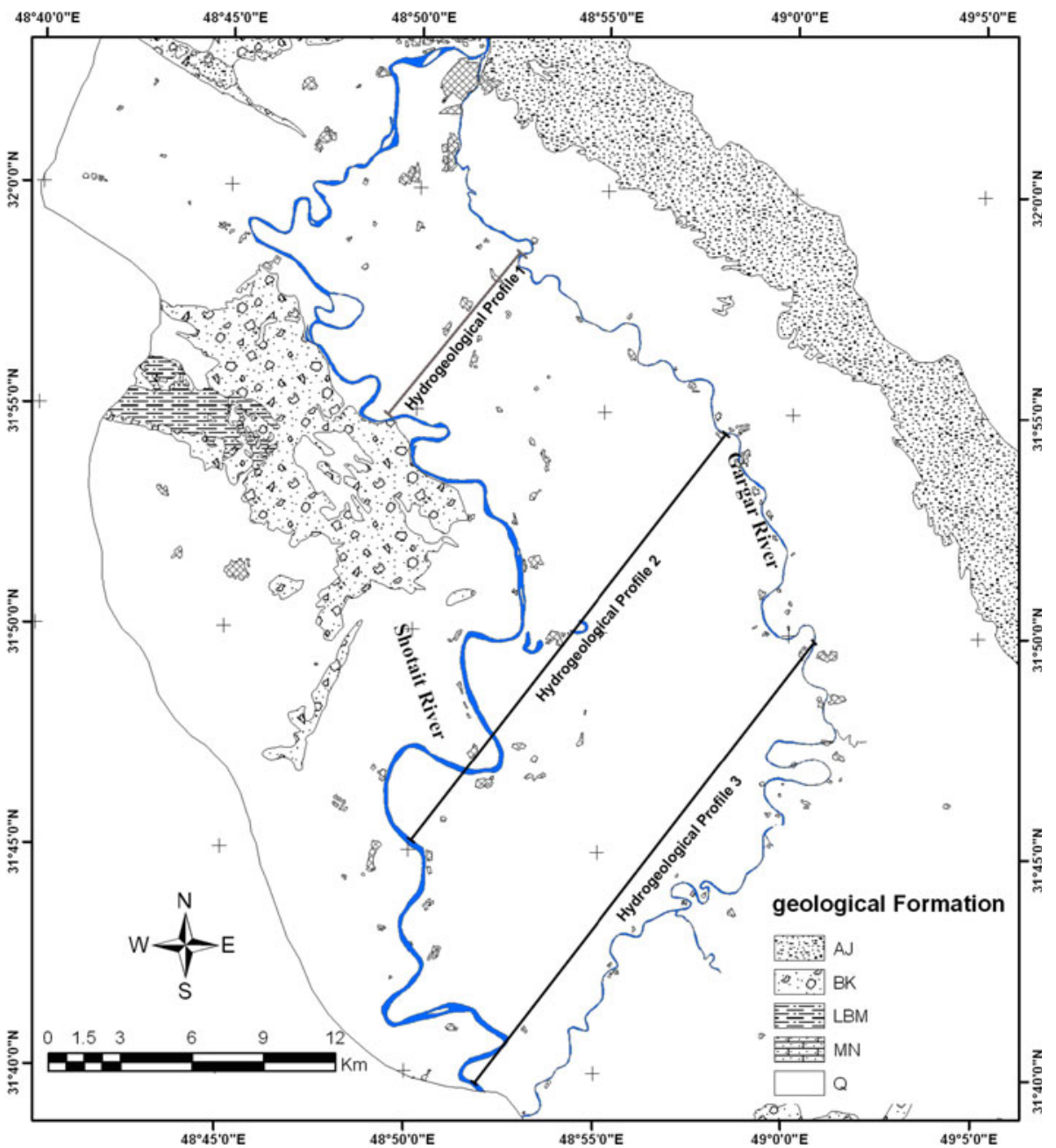

\section{Sampling and chemical analysis}

It is necessary to take into account the impact of the field stages on the chemical analysis of natural water, in terms of both sampling representativeness and spatial and temporal variability (Roy and Fouillac 2004). Sampling in the Mianab was done in 4 days in August 2006 because of huge consumption of pesticides in June and August so it is an appropriate time to detect the pesticides in the groundwater samples. Sampling locations were determined based on the expert judgment type (EPA 1995). Then, the sampling operators with a specific plan went to the sampling locations and carried out sampling. The samples were taken based on the standard sampling method from 37 wells (EPA 2003) and placed in dark glass bottles with 11 capacity and kept at $4{ }^{\circ} \mathrm{C}$ before handing to the laboratory in the pharmacy faculty of medicine, University of Kermanshah.

Sample preparation was done to extract the pesticides from water afterwards. Then, a simple and efficient automated method for extraction and pre-concentration was applied. In this method, a pyrrole-based polymer was synthesized and applied as an efficient sorbent for microsolid-phase extraction. After extraction, analytes were desorbed in ethyl acetate and analyzed using gas chromatography-flame (Ahmadi et al. 2008).

\section{Discussion and results}

Chemical analysis results from 37 groundwater samples for 2,4-D, permethrin, diazinon and clodinafop propargyl pesticides are shown in Table 1. The pesticides were not recognized in most of the samples which were gathered from the central and southern part of the study area. These results are marked by N.D. sign in Table 1; but in samples that were gathered from the north of study area, there is a high amount of pesticides. For example in the Longor village in the north of the study area, different peaks were appeared in retention time similar to 2,4-D, diazinon, permethrin and clodinafop propargyl (Fig. 6). Figure 6 is a chromatogram of a sample water which analysed by GC. 
Fig. 3 3D well logs located in the study area showing layer sequences including gravel, sand, silt and clay

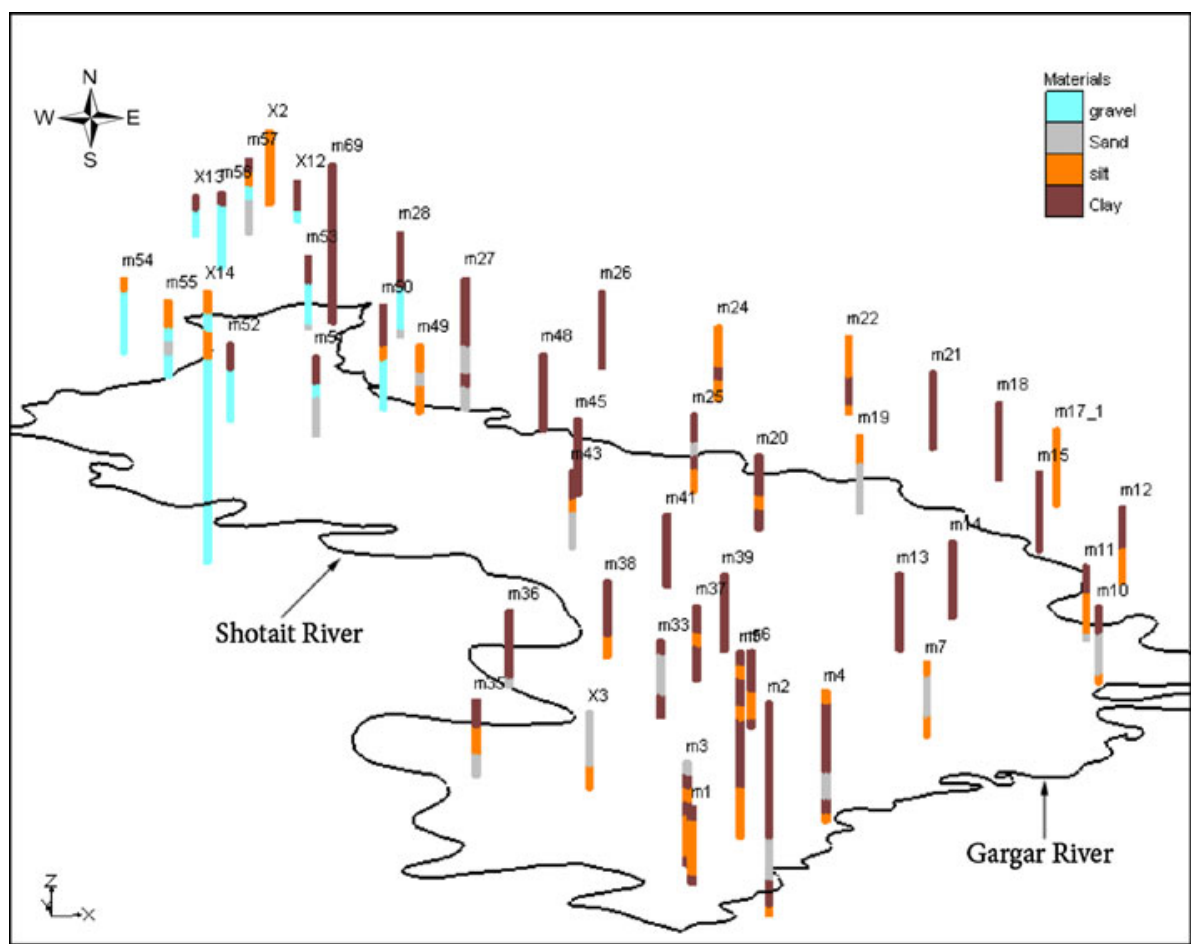

Fig. 4 Hydrogeological profiles: Hydrogeological Profile 1 showing the confined aquifer in the north part of the study area and Hydrogeological Profiles 2 and 3 showing the dominant unconfined aquifer in the central and south part of the study area, respectively (the hydrogeological profile plan view has shown in Fig. 2)

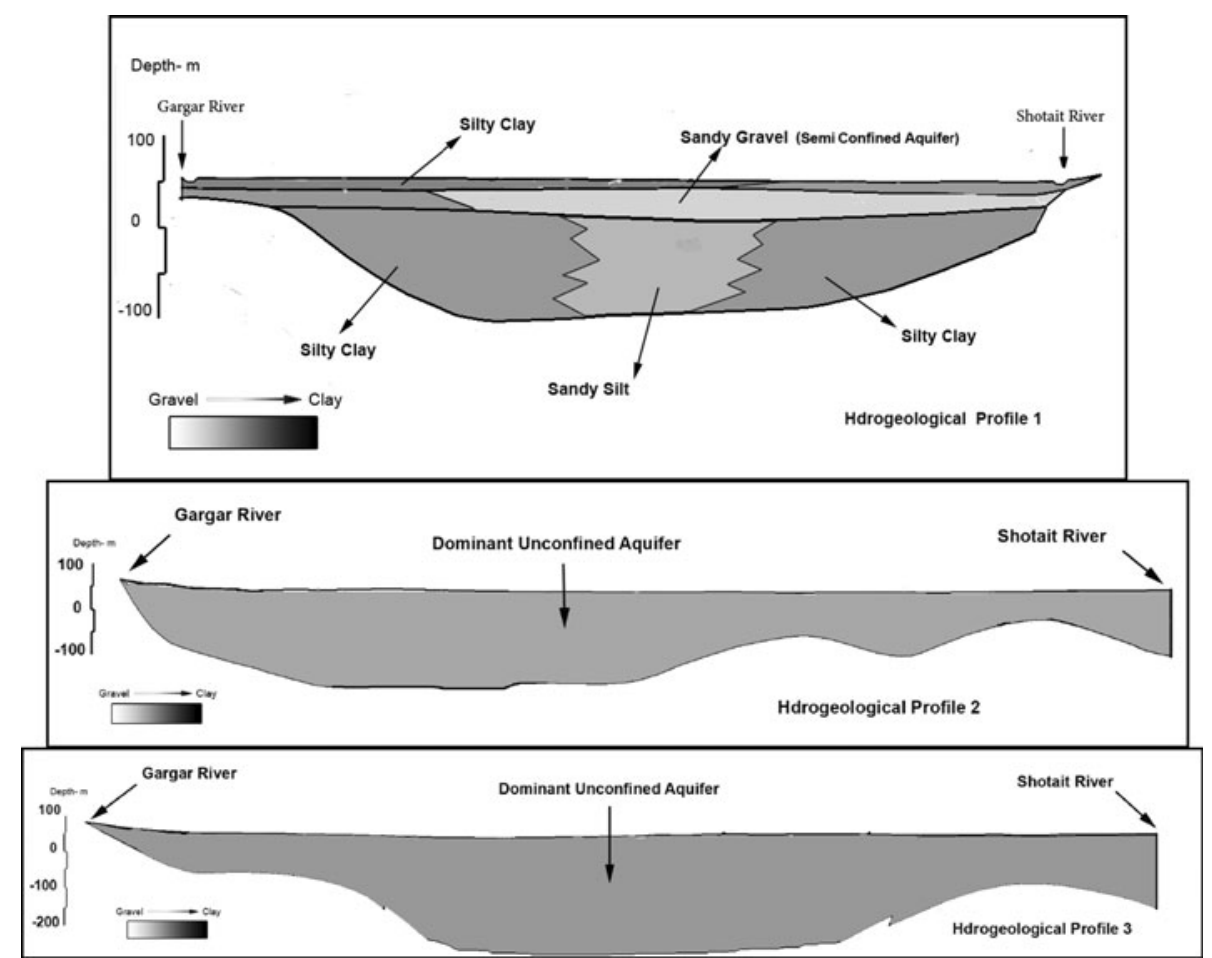

The vertical axis, according to the response of detector (Flame Ionization Detector, FID), is defined by Milli Volt or mVolt unit. The number marketed at each peak represents the retention time of pesticides in the column of Gas Chromatography instrument. Calculated statistical parameters, such as average, maximum, minimum and standard deviation, are also shown in Table 1.

Results from chemical analysis at the sampling points are shown as pie diagram in Fig. 7; in this figure, pesticides concentration ratio to sum of all 4 other pesticides in each 
Fig. 5 Iso-piezometric map and groundwater direction in the study area

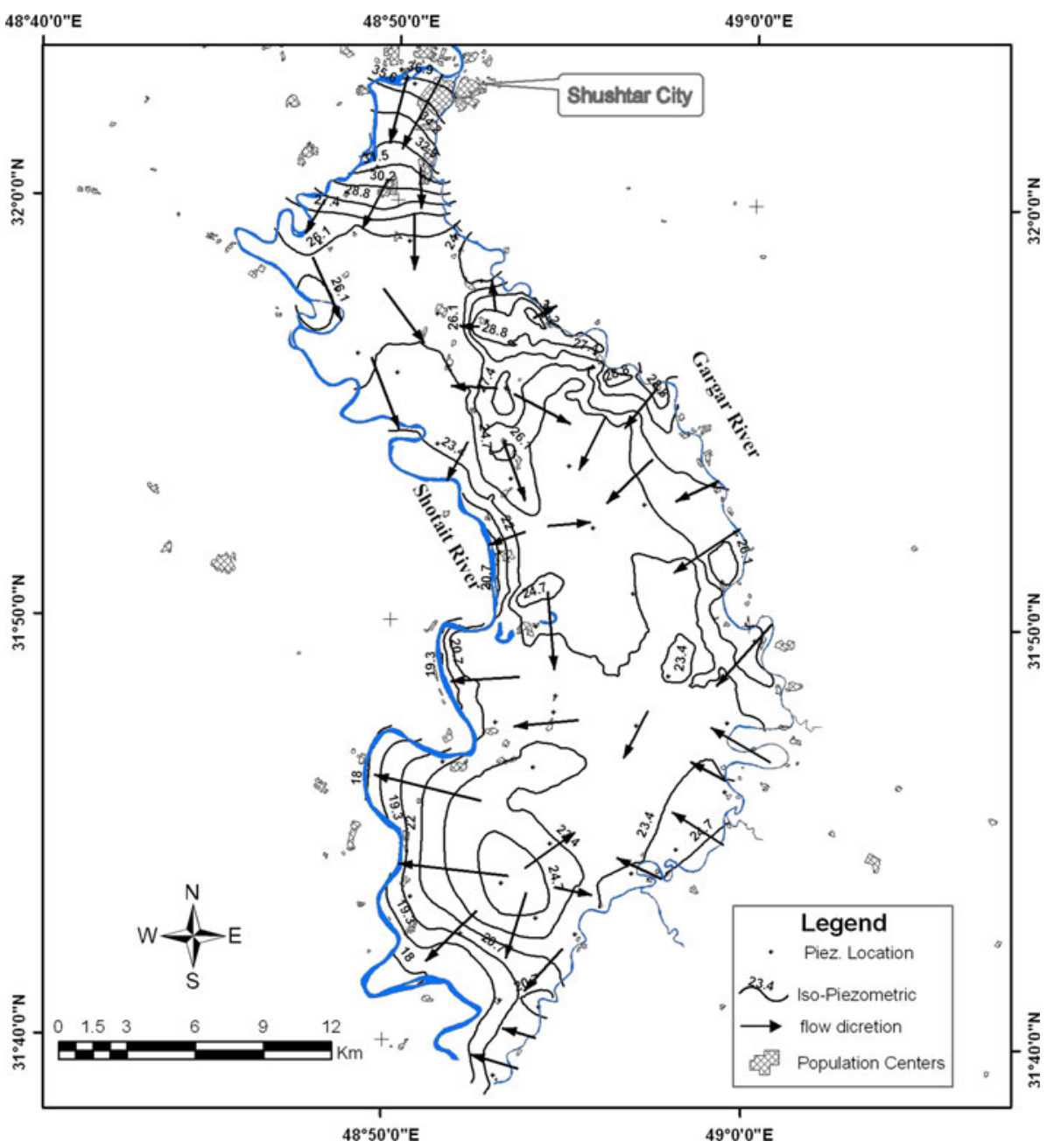

sample is shown. Points with no pie diagram means that in these points no pesticide was recognized (Fig. 7).

Among 4 pesticides assessed, 2,4-D has highest concentration value in the groundwater (15 ppm), and then permethrin, diazinon, and clodinafop propargyl have more concentration value, respectively. Maximum standard deviation is related to 2,4-D and minimum standard deviation is related to the clodinafop propargyl. 2,4-D has a relatively long half-life (200 days) and its high amount consumption are two reasons that 2,4-D concentration in groundwater is higher than the others; however, due to the lack of accurate information about amount of pesticides utilization (because of diversity in management), there is no detailed information about pesticides usage.

Wide-spread agricultural activities throughout the study area caused the pesticides existence in most samples with various pesticides concentration value.

Geology and soil type in the same agricultural conditions have an important effect on the groundwater contamination. Existence of Aghajari and Bakhtiari Formations and their erosion products resulted in formation of an aquifer which is composed of clay and gravel sediments, respectively. These sediments affect hydraulic conductivity which is one of the important parameters influencing the groundwater movement and contamination. For example because of high hydraulic conductivity and surface recharge in the northern part of the study area in comparison with the southern part, the transport of pesticides in the northern part is faster and the concentration of the pesticides in the groundwater samples is more.

As mentioned above, groundwater quality and quantity in the south of the study area is not in a good condition, so that it is not suitable for drinking and inevitably, it is just used for agricultural purposes. Lowest concentration values of pesticides are recorded in the south with similar agricultural activities conditions (same land-use) to the northern part of the plain. This shows that soil properties and upper sediments that form the aquifer have a preservative role against aquifer contamination caused by anthropogenic activities.

Coarse sediments such as sand and gravel that form the aquifer and the light soil texture in the north of the plain caused great surface recharge due to the agricultural 
Table 1 Analysis results of 37 groundwater samples in the study area to determine 2,4-D, permethrin, diazinon and clodinafop propargyl pesticides and statistical parameters of the pesticides (in micromole per liter)
SD. standard deviation, Max. maximum, Min. minimum, Avg. average

\begin{tabular}{|c|c|c|c|c|c|c|c|}
\hline Permethrin & Clodinafop & Diazinon & $2-4-D$ & Y-UTM & X-UTM & Index & Row \\
\hline 2.11 & N.D. & 0.23 & 15.03 & 3529374 & 299445 & S1 & 1 \\
\hline 0.13 & 0.27 & N.D. & N.D. & 3534448 & 298077 & $\mathrm{~S} 2$ & 2 \\
\hline 1.37 & 0.37 & 0.67 & 6.85 & 3537533 & 297619 & S3 & 3 \\
\hline 0.14 & N.D. & N.D. & N.D. & 3538909 & 298413 & $\mathrm{~S} 4$ & 4 \\
\hline 1.21 & 0.30 & 0.67 & 13.48 & 3541013 & 296780 & S5 & 5 \\
\hline N.D. & N.D. & 0.06 & 13.70 & 3545358 & 296377 & S6 & 6 \\
\hline 1.37 & 0.26 & N.D. & 0.05 & 3544216 & 294377 & S7 & 7 \\
\hline 0.87 & 0.43 & 0.84 & 0.05 & 3539719 & 295907 & S8 & 8 \\
\hline N.D. & N.D. & N.D & 0.62 & 3540707 & 232222 & S9 & 9 \\
\hline 0.10 & 0.47 & 2.08 & 8.36 & 3536226 & 296195 & S10 & 10 \\
\hline N D & N.D. & N D. & N.D. & 3535143 & 297271 & $\mathrm{~S} 11$ & 11 \\
\hline 0.18 & 0.98 & 1.92 & 6.85 & 3535350 & 294117 & S13 & 12 \\
\hline N.D. & N.D. & N.D. & 0.71 & 3538560 & 292608 & S14 & 13 \\
\hline N.D. & 0.02 & 0.19 & 1.22 & 3537378 & 301703 & $\mathrm{~S} 15$ & 14 \\
\hline N.D. & N.D. & 0.14 & N.D. & 3510746 & 301104 & S16 & 15 \\
\hline N.D. & N.D. & N.D. & N.D. & 3519938 & 302156 & S17 & 16 \\
\hline 2.54 & 0.28 & N.D. & N D. & 3523711 & 301402 & $\mathrm{~S} 18$ & 17 \\
\hline N.D. & 2.55 & N.D. & N.D. & 3531756 & 297054 & S19 & 18 \\
\hline N.D. & N.D. & 0.10 & 0.95 & 3535709 & 303986 & $\mathrm{~S} 20$ & 19 \\
\hline N.D. & N.D. & N.D. & 0.71 & 3534355 & 306591 & $\mathrm{~S} 21$ & 20 \\
\hline 0.02 & N.D. & N.D. & 0.57 & 3532203 & 308118 & $\mathrm{~S} 22$ & 21 \\
\hline N.D. & 0.08 & N.D. & N.D. & 3529933 & 309241 & $\mathrm{~S} 23$ & 22 \\
\hline N.D. & N.D. & N.D. & 0.08 & 3527897 & 310224 & $\mathrm{~S} 24$ & 23 \\
\hline N.D. & N.D. & N.D. & N.D. & 3525647 & 309580 & $\mathrm{~S} 25$ & 24 \\
\hline N.D. & N.D. & N.D. & N.D. & 3523038 & 311016 & S26 & 25 \\
\hline N.D. & N.D. & N.D. & N.D. & 3519438 & 309796 & $\mathrm{~S} 27$ & 26 \\
\hline N.D. & 0.10 & 0.20 & N.D. & 3516405 & 305812 & $\mathrm{~S} 28$ & 27 \\
\hline N.D. & N.D. & N.D. & N.D. & 3516405 & 309692 & $\mathrm{~S} 29$ & 28 \\
\hline N.D. & N.D. & N.D. & N.D. & 3519855 & 307555 & $\mathrm{~S} 30$ & 29 \\
\hline N.D. & N.D. & N.D. & 0.07 & 3512824 & 305588 & S31 & 30 \\
\hline N.D. & 0.01 & N.D. & N.D. & 3517505 & 301264 & $\mathrm{~S} 32$ & 31 \\
\hline N.D. & N.D. & N.D. & N.D. & 3517747 & 297295 & S33 & 32 \\
\hline N.D. & 0.18 & 0.11 & 0.93 & 3510189 & 298067 & S34 & 33 \\
\hline N.D. & N.D. & 0.26 & N.D. & 3510133 & 303102 & S36 & 34 \\
\hline N.D. & N.D. & N.D. & 0.93 & 3506957 & 301496 & S37 & 35 \\
\hline N.D. & N.D. & N.D. & N.D. & 3507248 & 299791 & S38 & 36 \\
\hline 0.01 & N.D. & N.D. & 0.14 & 3503938 & 299487 & S39 & 37 \\
\hline Permethrin & \multicolumn{2}{|c|}{ Clodinafop } & \multicolumn{2}{|c|}{ Diazinon } & $2-4-D$ & \multicolumn{2}{|c|}{ Parameters } \\
\hline 0.88 & \multicolumn{2}{|c|}{0.65} & \multicolumn{2}{|l|}{0.68} & 5.26 & \multicolumn{2}{|c|}{ SD. } \\
\hline 2.54 & \multicolumn{2}{|c|}{2.55} & \multicolumn{2}{|l|}{2.08} & 15.03 & \multicolumn{2}{|c|}{ Max. } \\
\hline 0.01 & \multicolumn{2}{|c|}{0.01} & \multicolumn{2}{|l|}{0.06} & 0.05 & \multicolumn{2}{|c|}{ Min. } \\
\hline 0.84 & \multicolumn{2}{|c|}{0.45} & \multicolumn{2}{|l|}{0.57} & 3.75 & \multicolumn{2}{|c|}{ Avg. } \\
\hline
\end{tabular}

Distribution pattern of population centers which increase northward the study area, and the role of groundwater as the main source of drinking water are the two important issues that must be taken into account in the management of pesticides use. The prevention of illnesses, especially in children, due to groundwater contamination by pesticides 
Fig. 6 Chromatogram of groundwater sample S11- Longor village
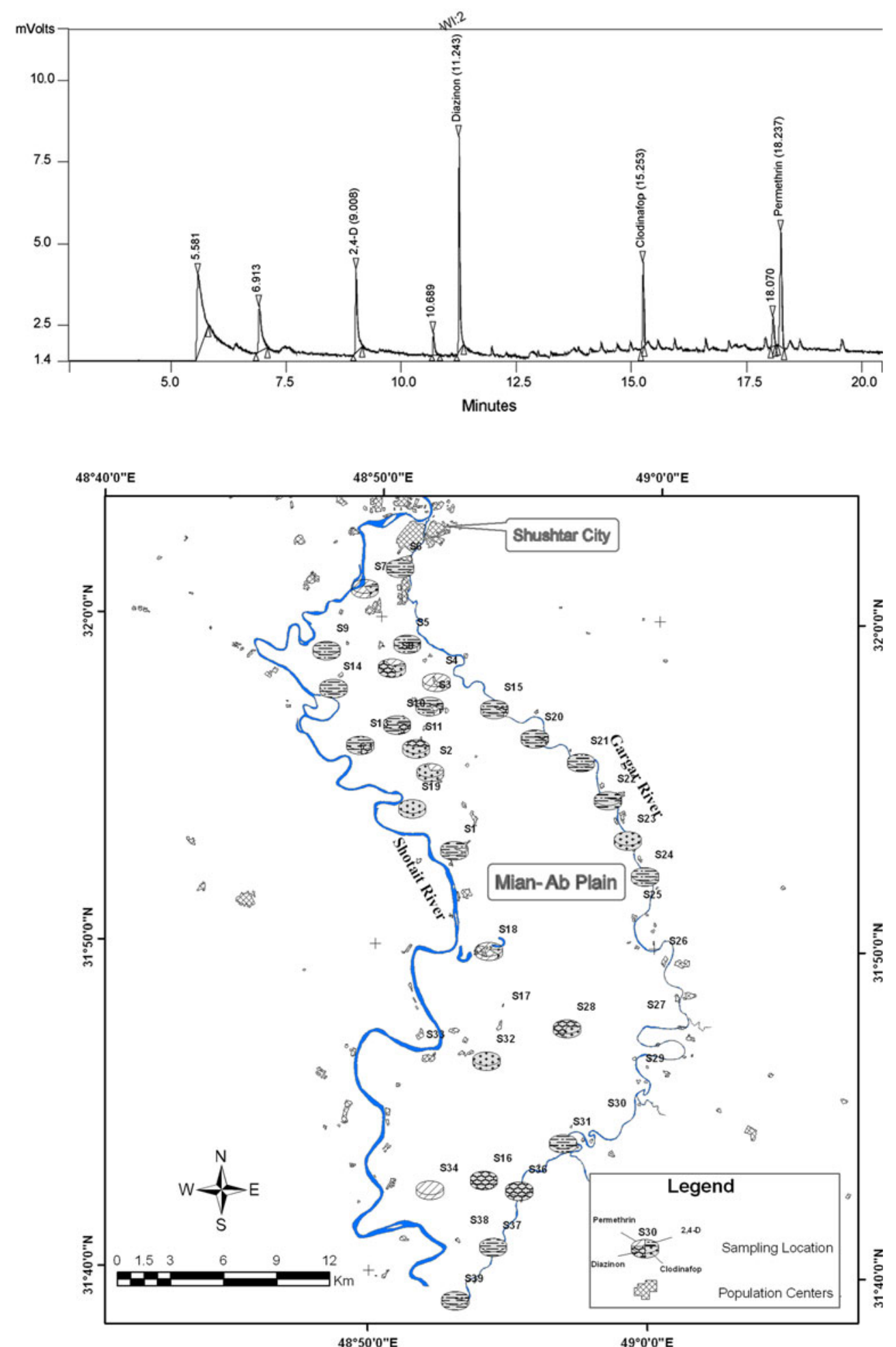

Fig. 7 Results from chemical analysis of the groundwater samples as pie diagram for pesticides must be taken into account. Irregular consumption of pesticides also caused contamination and the pesticides are transmitted to agricultural products (Ebadi et al. 2005).

Pesticides concentration values were not dangerous for human health based on the results from studies performed on the wells and rivers around Tehran City (Ahmadi et al. 2006). However, in the present study the pesticides concentration in half of samples was higher than the EPA maximum contaminant level and besides influence of geological and hydrogeological properties is considered too. 
Interaction between surface and groundwater brings some variations in the chemical composition in the both sources (Delleur 2007).

Contaminated groundwater transmission to the Shotait river (a branch of Karun river) caused contamination of surface-water that it is used as agricultural water; however, pesticides in a losing river may cause its influx to the groundwater. We suggest to use some contaminant transport models such as MT3DMS to estimate transmitted pesticides values in rivers.

Agriculture development in this area is possible by performing the Irrigation-Drainage Project all around the plain. If this project is carried out, the agricultural industry will develop irregularly. So the groundwater level will rise, as a result land becomes muddy and so more pesticides will be transmitted to the aquifer and the risk of contamination increases.

\section{Conclusion}

Groundwater is an important resource for drinking and agricultural consumptions in the study area. Therefore, groundwater quality assessment is very important. Based on the exploration studies, in some parts of the plain the aquifer becomes semi-confined due to the existence of the impermeable clayey layers. The existence of heavy soil, which is mostly composed of clay and dominates in the south, caused changes in the concentration of groundwater pesticides in the south and north of the study area.

Based on results from the analysis of 37 samples that was carried out on 4 pesticides (2,4-D, diazinon, permethrin and clodinafop propargyl), it was determined that pesticides concentration values in the groundwater in the north of the plain are higher where highly permeable sediments with light soil texture dominates compared to the southern part.

Existence of impermeable clayey layer in the southern part of the plain caused an intensive decrease in the pesticides concentration. About $50 \%$ of the groundwater samples have concentration values more than maximum contamination level based on EPA drinking standards. High concentration of pesticides in groundwater in the north of plain is an important issue from environmental point of view. It gets more critical when it is clarified that the wells located in the north of the plain are the major supply of drinking water and most of the population centers are located there, as well.

Open Access This article is distributed under the terms of the Creative Commons Attribution Noncommercial License which permits any noncommercial use, distribution, and reproduction in any medium, provided the original author(s) and source are credited.

\section{References}

Ahmadi F, Assadi Y, Milani Hosseini SMR, Rezaee M (2006) Determination of organophosphorus pesticides in water samples by single drop microextraction and gas chromatography-flame photometric detector. J Chromatogr A 1101(1-2):307-312

Ahmadi F, Shahsavari AA, Rahimi-Nasrabadi M (2008) Automated extraction and preconcentration of multiresidue of pesticides on a micro-solid-phase extraction system based on polypyrrole as sorbent and off-line monitoring by gas chromatography-flame ionization detection. J Chromatogr A 1193(1-2):26-31

Carson RL (1962) Silent spring, Riversde Press, Cambridge

Delleur JW (2007) The handbook of groundwater engineering, 2nd edn. CRC Press, Boca Raton

Ebadi AG, Shokrzadeh M, Zare S (2005) A survey and measurement of residues of lindane (organochlorine pesticides) in cultivated cucumber of Mazandaran Province (Iran). Pak J Nutr 4(5): 291-293

EPA (1995) Superfund program representative sampling guidance

EPA (2003) Guidance on choosing a sampling design for environmental data collection, QA/G-5S

EPA (2006) 2006 Edition of the Drinking Water Standards and Health Advisories, 822-R-06-013, Office of Water

Hashemy-Tonkabony SE, Afshar A, Ghazisaidi K, Assadi-Langaroodi F, Messchi M, Ahmadi Z (1981) Chlorinated pesticide residues in meat and fat from animals raised in Iran, JAOCS

Jalali M, Kolahchi Z (2008) Groundwater quality in an irrigated, agricultural area of northern Malayer, western Iran. Nutr Cycl Agroecosyst 80:95-105. doi:10.1007/s10705-007-9123-5

Jiang Y, Wu Y, Groves C, Yuan D, Kambesis P (2009) Natural and anthropogenic factors affecting the groundwater quality in the Nandong karst underground river system in Yunan, China. J Contam Hydrol 109(1-4):49-61

Khuzestan Water and Power Authority (1987) Geophysics Assessments of Gargar, Mian-Ab and Shoaibie Plains

Kim JH, Kim RH, Lee J, Chang HW (2003) Hydrogeochemical characterization of major factors affecting the quality of shallow groundwater in the coastal area at Kimje in South Korea. Environ Geol 44:478-489. doi:10.1007/s00254-003-0782-5

Liu RC, Hahn C, Hurtt ME (1996) The direct effect of hepatic peroxisome proliferators on rat leydig cell function in vitro. Fundam Appl Toxicol 30:102-108

Lorite-Herrera M, Jiménez-Espinosa R (2007) Impact of agricultural activity and geologic controls on groundwater quality of the alluvial aquifer of the Guadalquivir River (province of Jaén, Spain): a case study. Environ Geol 54:1391-1402. doi: 10.1007/s00254-007-0920-6

Mahab Ghods Consultant Engineering (1986) Karun Irrigation Projects

Pimentel D (1995) Amounts of pesticides reaching target pests: environmental impacts and ethics. J Agric Environ Ethic 8:17-29

Roy S, Fouillac A-M (2004) Uncertainties related to sampling and their impact on the chemical analysis of groundwater. Trends Anal Chem 23(3):185-193

Shomar BH, Muller G, Yahya A (2005) Occurence of Pesticides in Groundwater and Topsoil of the Gaza Strip. Water Air Soil Pollut. doi:10.1007/s11270-005-9038-1

Sierra Club of Canada (2005) Overview of the toxic effects of 2,4-D, 412-1 Nicholas St., Ottawa, ON K1 N 7B7,613-241-4611

UNEP (1993) The Aral Sea: diagnostic study for the development of an action plan for the conservation of the Aral Sea, United Nations Environment Programme (UNEP), Nairobi, Kenya (1993)

Waxman MF (1998) Agrochemical and pesticide safety handbook. Lewis Publishers, Boca Raton 